\title{
ANALYSIS OF BILLBOARD CONTRIBUTION TAX TO REGIONAL INCOME OF SUKOHARJO DISTRICT IN YEAR 2012-2016
}

\author{
Suhesti Ningsih \\ College of Economics - AAS Surakarta \\ Email : hesti.hegi@gmail.com
}

\begin{abstract}
The purpose of this study was to determine the level of contribution of the advertisement tax on revenue, which in the era of regional autonomy, local governments are required to always improve the reception area, such as an increase in local tax revenue through advertising tax receipts. This research applies descriptive analysis method, wherein the method is used to provide a systematic explanation, actual and accurate statement of fact, and just describe situations or events not to seek or explain the relationships and testing hypotheses. From the analysis of the data shows thatSukoharjo advertisement tax revenue from the year 2012-2016 reached an average of $119.02 \%$.Advertisement tax contribution rate to the Local Tax reached an average $3.06 \%$, to the level of the advertisement tax revenue contribution to the local revenue of the year 2012-2016 is still in very less criteria with an average $1.50 \%$.
\end{abstract}

Keywords : Autonomy, Advertisement Tax, Local Tax, Local Revenue

\section{INTRODUCTION}

\subsection{Background}

Regional autonomy is one manifestation of the reform of the regional administration of the provincial / district / city in order to anticipate the demands of constitutional changes both socially and politically that comes from within the country and abroad. The first law on the basis of regional autonomy is Law No. 32 of 2004 on Regional Government and Law No. 33 of 2004 on Financial Balance between Central and Regional.

One of benchmarks to see the readiness of a region in the implementation of regional autonomy is to measure how much the financial ability of an area to organizes regional autonomy or self-government. Financial resources is one of them comes from the original income (PAD), which is one source of revenue from taxes, retribution, the management of separated areas, and other legitimate local revenue.

Local taxes according to Kesit Bambang Prakosa (2005), is a compulsory levy on the individual or entity that carried out by local governments without direct payment balance, which can be imposed by legislation in force, which is used to finance the implementation of local government and regional development,

With the increasing development of the sectorindustrial businesses such as malls, hotels, restaurants, and services is a potential business sector in Sukoharjo district. The times and technology very rapidly result in higher consumption and adjust your lifestyle trends. In the business world, marketing communications is one of the most important aspects of the overall marketing activities as well as a determinant of the success of 
marketing. Due to intense competition in the business world, advertising is not enough just through the TV and radio media, therefore, the billboard is the right advertising medium to promote products and services to the public.

Billboards are objects, equipment, action orthe media according to the shape and arrangement of manifold types are designed for commercial purposes, introduce, encourage, promote, or to draw public attention to goods, services, persons or entities that can be seen, read, heard, tasted, or enjoyed by the public. Advertisement tax is one source of revenue potential in Sukoharjo district as a source of financing to support the implementation of government and regional development.

\subsection{Formulation of the Problem}

Based on the description above, it will be discussed the issues of which will be examined in the writing of this final report, in accordance with the proposed title, namely:

1. How targets and realization of revenue from advertisement tax for the period of 2012-2016

2. How Advertising Tax contribution to the Local Tax Revenue and Local Revenue Sukoharjo district for the period 20122016

3. Any constraints faced by the Finance Agency Daereh Sukoharjo in the process of advertisement taxation

4. How to efforts made by the Financial Agency (BKD) Sukoharjo in the process of advertisement taxation

\subsection{Research Purposes}

The objectives of this study are:
1. Knowing targets and realization of revenue from advertisement tax for the period of 2012-2016

2. Knowing Advertising Tax contribution to the Local Tax Revenue and Local Revenue for the period 2012-2016

3. To find out the constraints faced by the Regional Finance Agency Sukoharjo in the process of advertisement taxation

4. To know the efforts that faced by the Local Finance Board Sukoharjo in the process of advertisement taxation

\section{THEORITICAL REVIEW}

\subsection{Tax}

According Soemitro in Mardiasmo (2016) Taxes are the contributions of the people to the state treasury by law (enforceable) with no lead gets services (contra) directly demonstrated and used to pay for general expenses.

According to SI Djajadiningrat in Siti Official (2016) Tax as suatau obligation to give up some of the wealth to the state treasury due to a state, events, and actions that provide a certain position, according to the regulations set by the government and can be enforced, but there is no merit reciprocal of the state directly, to maintain the general welfare.

According to Law No. Taxation General Provisions16 of 2009 Tax is a mandatory contribution to the state tax owed by individuals or entities that are enforceable under the law, by not getting the rewards directly and used for the purposes of state for the greatest prosperity of the people.

According Mardiasmo, 2016, the tax has two functions: fUNCTION Budgetair and Function Set (regulerend. Function Budgetair 
are tax as a source of funds for the government to finance expendituresexpenditures. Function Set (regulerend) is as a tool to organize or carry out government policy in social and economic fields.

According to the agency consists of tax levied tax and local tax center. Tax Center, which is a tax levied by the central government and used to fund household countries like (Income Tax), Value Added Tax (VAT and Sales Tax on Luxury Goods (Sales Tax), Land and Building Tax (PBB), and Stamp Duty . local Taxes, which is a tax levied by local governments and used to fund local households.

\subsection{Local Tax}

Local taxis a mandatory fee to do the individual or entity to areas without immediate rewards that can be imposed by legislation in force applicable to finance the implementation of the Local Government and Regional Development (Mardiasmo, 2016).

According to Davey (1988) tax collection area by the municipality / district to the community is basically intended to finance the implementation of the task of governance, development and social development secra efficient and effective in efforts to improve people's lives.

Based on the law No.28 of 2009 on Local Taxes and Levies, Local Taxes can be classified into two types, namely:

1. Provincial tax (tax on motor vehicles,Customs of Vehicle, Surface Water Tax, and Tax Cigarettes).

2. Tax District / City,consisting of hotel tax, restaurant tax, entertainment tax, advertisement tax, street lighting tax, tax nonmetallic minerals and rocks, parking tax, water tax land, tax birds' nests, property tax in rural and urban areas, customs perolahan land rights and buildings.

\subsection{Advertisement Tax}

Based on Sukoharjo local regulation No. 7 of 2011 the billboard tax is a tax on the implementation of the billboard. While understanding the advertisement itself is the object, instrument, deed, or media forms and manifold types are designed for commercial purposes to introduce, encourage, promote, or to draw public attention to goods, services, persons or entities, which can be seen, read, heard, felt and enjoyed by the public.

Advertisement tax subject is an individualor bodies organizing or install billboards. While the object of advertisement tax that isadvertisement boards or billboards, reklame Megatron / vidiotron / large electronic display (led), Advertisement cloth, attached billboards, stickers, advertising flyers, billboards running, including in vehicles, aerial billboards, billboards floating, voice advertisement, advertising film / slide and billboard display

Which is not included as the object of the advertisement tax that is

1. Implementation of advertisement through (C) Internet, television, radio, newspapers, magazines.

2. Label / branded products attached to goods traded, which serves to differentiate it from other similar products.

3. Business or profession identifier name attached attached to the building where the business or profession conducted by 
the size does not exceed $1 \mathrm{~m} 2$ (one square meter).

4. Billboards held by the Government or Local Government.

5. Implementation advertisement by political organizations / social / societal solely for the sake of political / social / community concerned

Basic tariffsand procedures for the advertisement tax calculation according to local regulations Sukoharjo district No. 7 of 2011 are as follows:

1. Basic Tax advertisement advertisement rental value.

2. Incase held by a third party advertisement, advertisement rental value is determined based on the Contract Advertising.

3. In the event held its own advertisement, Advertising Rental Value is calculatedby taking into account the type, the materials used, the location of the placement, the period of implementation, the number and size of the advertisement media.

4. In terms of rental value Advertisingnot known or is not reasonably foreseeable. Billboards rental value determined by using factor type, materials used, placement location, period of implementation, the number and size of advertisement media.

5. Billboards rental value calculation method determined by the calculation period multiplied size multiplied by the unit price plus the value of the location of placement.

6. Rental value calculation results Reklame governed by decree.

7. fare Advertising Tax is set at $25 \%$ (twenty five percent).
Tax Payable $=\times$ Tax Rate Tax Base

Tax rate $=\times$ Value Rental Advertising

\subsection{Local Revenue (PAD)}

Understanding local revenues based on Law No. 33 of 2004 on Financial Balance between Central and Regional Article 1 paragraph 18 that "revenue, hereinafter referred to as PAD is earned income areas levied by local regulations in accordance with the legislation".

According Mardiasmo (2016) revenue is the reception area of a sector of local taxes, levies, local owned company results, the results of which are separated regional wealth management, and other legitimate local revenue.

\subsection{Previous Research}

Results of research that has been done by Fitriany (2012) in Pontianak district shows that the contribution made to the advertisement tax revenue Pontianak regency in 2009 amounted to $0.84 \%$ in 2010 amounted to $0.79 \%$ and in 2011 amounted to $1.01 \%$,

Indrawan (2015) which examined the contribution of the advertisement tax in Bandung, it can be concluded that the advertisement tax contribution does not significantly affect local revenues in Bandung. The magnitude of the effect of the advertisement tax contribution to local revenues amounted to $4.2 \%$ while the remaining $95.8 \%$ influenced by other taxes that are not included into the study variables.

Research conducted by the Ancient and Ginting (2016) that the statistical test either partially or simultaneously indicates 
International Journal of Economics, Business and Accounting Research (IJEBAR)

Peer Reviewed - International Journal

Vol-1, Issue-1, 2017 (IJEBAR)

ISSN: 2614-1280

http://jurnal.stie-aas.ac.id/index.php/IJEBAR

that the advertisement tax and street lighting tax has no effect on revenue.

\section{RESEARCH METHOD}

\subsection{Population and Sample}

The population in this study is in the form of Target and Local Tax Revenues Sukoharjo district. The sample used is data in the form of Target and Actual Receipts Tax Sukoharjo advertisement fiscal year 20122016.

\subsection{Types, Techniques and Analysis}

This research is a descriptive study, the research describes and aims to provide an overview and explanation of the variables examined in this case is "Analysis of Advertisement Tax Contributions In Boosting revenue (PAD) in Sukoharjo"

Techniques and analysis undertaken in this study is through several steps, namely:

1. Creating a target table and advertisement tax revenue realization Sukoharjo district, to determine the effectiveness of advertisement tax revenue using the formula:

$$
\frac{\text { Realisasi }}{\text { Target }} \times 100 \%
$$

table 1

Effectiveness Criteria Tax

\begin{tabular}{cc}
\hline Percentage & Criteria \\
\hline$>\mathbf{9 0 \%}$ & Effective \\
\hline $\mathbf{8 5 \% - 9 0 \%}$ & Effective enough \\
\hline$<\mathbf{8 5 \%}$ & Less effective \\
\hline
\end{tabular}

(Source: Arikunto, 2002)

2. Establish a table of advertisement tax growth rate over five years (2012-2016), using the formula:

$$
G t=\frac{X t-X_{(t-1)}}{X_{(t-1)}} \times 100 \%
$$

Abdul Halim, (2004)

Information :

xt Realization of tax revenue given year advertisement

$\mathrm{X}(\mathrm{t}-1)$ : Realized revenues the previous year advertisement tax

3. Establish a table of advertisement tax contribution to the Regional Tax Sukoharjo district, according to the formula:

$$
\frac{X}{Y} \times 100 \%
$$

Sadono Sukirno (1985)

Information :

$\mathrm{X}$ : Advertising Tax receipts

Y : Realization of revenue from advertisement tax

4. Arrange tables advertisement tax contribution to regional revenue Sukoharjo district, according to the formula:

$$
\frac{X}{Y} \times 100 \%
$$

Sadono Sukirno (1985)

Information :

$\mathrm{X}$ : Advertising Tax receipts

$\mathrm{Y}$ : Realization of revenue from local revenue

The following table advertisement tax contributions to the assessment criteria: 
International Journal of Economics, Business and Accounting Research (IJEBAR)

Peer Reviewed - International Journal

Vol-1, Issue-1, 2017 (IJEBAR)

ISSN: 2614-1280

http://jurnal.stie-aas.ac.id/index.php/IJEBAR

Table 2

Criteria Value Contributions

\begin{tabular}{cc}
\hline Percentage & Criteria \\
\hline $\mathbf{0}$ to $\mathbf{1 0 . 0 0}$ & Very less \\
$\mathbf{1 0 . 1 0}$ to 20.00 & Less \\
$\mathbf{2 0 . 1 0}$ to 30.00 & Enough \\
$\mathbf{3 0 . 1 0}$ to 40.00 & moderate \\
$\mathbf{4 0 . 1 0}$ to 50.00 & Well \\
\hline$>\mathbf{5 0 . 0 0}$ & Very good \\
\hline Source:MOHA Litbag team-UGM 1991
\end{tabular}

\section{RESULTS AND DISCUSSION}

\subsection{Target and Advertisement Tax Revenues in 2012-2016}

Tax Collection System in the Field of Income Sukoharjo for implementing official advertising tax assessment system. In the system authorizes the government to calculate the amount of tax payable will be paid by the taxpayer.Based on local revenue budget realization reports in 2012-2016 Finance Agency Sukoharjo regency is known in the following table:

table 3

Target Data and Advertising Tax Revenues

Sukoharjo district in 2012-2016

\begin{tabular}{cccc}
\hline Year & Target & Realization & Percentage \\
\hline $\mathbf{2 0 1 2}$ & Rp. 2,000,000,000 & Rp. 2589471200 & $129.47 \%$ \\
\hline $\mathbf{2 0 1 3}$ & Rp. 3.175 billion & Rp. 4228787275 & $133.19 \%$ \\
\hline $\mathbf{2 0 1 4}$ & Rp. 3.175 billion & $\begin{array}{c}\text { Rp. 3.693997 } \\
\text { billion }\end{array}$ & $116.35 \%$ \\
& & Rp. 3721488660 & $117.21 \%$ \\
\hline $\mathbf{2 0 1 5}$ & Rp. 3.175 billion & Rp. 4839583793 & $107.55 \%$ \\
\hline $\mathbf{2 0 1 6}$ & Rp. 4.5 billion & Average & $119.02 \%$ \\
\hline
\end{tabular}

Source: BKD Sukoharjo (data processing)

Comparing the advertisement tax revenue with the advertisement tax revenue targets have been set. Advertisement tax revenue is said to be effective if the percentage of advertisement tax revenue reached
$100 \%$.Based on the analysis, it is known that the advertisement tax revenue Sukoharjo district in 2012 through 2016 is very high. In 2012 through 2016, advertisement tax revenue Sukoharjo district reached an average of $119.02 \%$. 
International Journal of Economics, Business and Accounting Research (IJEBAR)

Peer Reviewed - International Journal

Vol-1, Issue-1, 2017 (IJEBAR)

ISSN: 2614-1280

http://jurnal.stie-aas.ac.id/index.php/IJEBAR

4.2 Advertising Tax Growth Rate in Sukoharjo district in 2012-2016

Table 4

Advertising Tax Revenue Growth Rate

Sukoharjo district in 2012-2016

\begin{tabular}{ccc}
\hline Year & Realization & Percentage \\
\hline $\mathbf{2 0 1 2}$ & Rp. 2589471200 & - \\
\hline $\mathbf{2 0 1 3}$ & Rp. 4228787275 & $63.00 \%$ \\
\hline $\mathbf{2 0 1 4}$ & Rp. 3.693997 billion & $-13.00 \%$ \\
\hline $\mathbf{2 0 1 5}$ & Rp. 3721488660 & $1.00 \%$ \\
\hline $\mathbf{2 0 1 6}$ & Rp. 4839583793 & $30.00 \%$
\end{tabular}

Source: BKD Sukoharjo (data processing)

The charts advertisement tax growth rate from 2012 through 2016 advertisement tax receipts fluctuated, indicating the lowest level achievements in 2012 and the highest level achievement was in 2016 (Figure 1)

Graph Advertising Tax Revenue Growth Rate

Sukoharjo district in 2012-2016

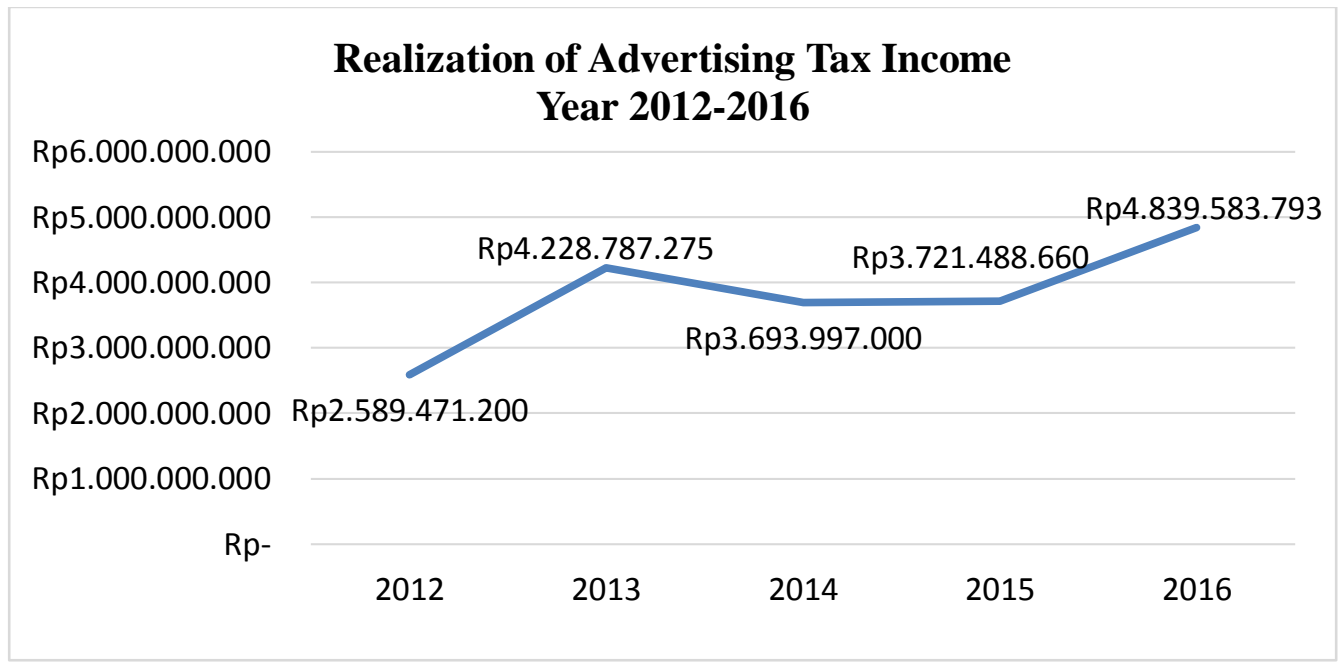

4.3 Advertising Tax contribution to the Local Tax Revenue and Local Revenue Sukoharjo district for the period 20122016

Analysis of the contribution is an analysis tool that is used to determine how much the contribution that can be donated from advertisement tax revenue, local taxes, budget revenues and expenditures Sukoharjo (Budiyuwono, 1995). Use of the analysis can be seenadvertisement tax role in contributing to the local tax, advertisement tax and role in contributing to local revenues Sukoharjo district.

Contributions are calculated by comparing the actual amount of local taxes to 
International Journal of Economics, Business and Accounting Research (IJEBAR)

Peer Reviewed - International Journal

Vol-1, Issue-1, 2017 (IJEBAR)

ISSN: 2614-1280

http://jurnal.stie-aas.ac.id/index.php/IJEBAR

local revenue. Local tax is said to have a major contribution if the result of the

Results of the calculations are presented calculation is more than $50 \%$. in the table below:

Table 5

Contributions of Revenue Advertising and PAD

Sukoharjo district in 2012-2016

\begin{tabular}{|c|c|c|c|}
\hline Year & Advertisement tax & PAD & Percentage \\
\hline 2012 & Rp. 2589471200 & Rp. 164954318824 & $1.57 \%$ \\
\hline 2013 & Rp. 4228787275 & Rp. 192971720442 & $2.19 \%$ \\
\hline 2014 & Rp. 3.693997 billion & Rp. 264814413083 & $1.39 \%$ \\
\hline 2015 & Rp. 3721488660 & Rp. 313947492011 & $1.19 \%$ \\
\hline 2016 & Rp. 4839583793 & Rp. 335071057676 & $1.44 \%$ \\
\hline \multicolumn{3}{|c|}{ Average } & $1.50 \%$ \\
\hline
\end{tabular}

Source: BKD Sukoharjo (data processing)

Table 5 shows that the contribution of the advertisement tax to PAD in Sukoharjo years 2012-2016 fluctuated enough. The average contribution to the PAD advertisement tax of $1.50 \%$. It shows that the contribution of the advertisement tax included in the criteria is very less. The results are consistent with penenlitian conducted by fitriani (2012), and researchIndrawan (2015). But contrary to penenlitian results showing that the advertisement tax does not affect the First Tax Regions.

In 2013 the contribution of billboards has increased from the previous year. Advertisement tax contribution increased by $0.65 \%$ from $1.57 \%$ in 2012 to $2.19 \%$ in 2013 . In 2014 a decline of $0.80 \%$ from $2.19 \%$ in 2013 to $1.39 \%$ in 2014 and 2015 decreased again by $0.21 \%$ from $1.39 \%$ in 2014 to $1.19 \%$ in 2015. Then in 2016, an increase of $0.26 \%$ from $1.19 \%$ in the year 2015 to $1.44 \%$ in 2016.

\subsection{Obstacles Anything Faced by Local Finance Board Sukoharjo in Advertising Tax Collection Process}

There are several obstacles encountered by Sector Income BKD Sukoharjo district in the Implementation of advertisement taxation. These barriers are divided into two, namely:

1. The resistance of the internal

a. The lack of facilities and infrastructurethe demolition of billboards that have expired. Facilities and infrastructure field includes cars, trucks, household appliances, and a helmet as a safety

b. Lack of fieldto oversee the implementation of the advertisement tax. Field workers who oversee, monitor, and regulate billboards now still little and tidaksebanding with the number of billboards installed in the district of Sukoharjo

c. The lack of active role of the Sector Income Sukoharjo district in the dissemination of the advertising tax to 
the public, causing a lack of awareness of the taxpayer in carrying out tax obligations.

2. The resistance of the external

a. Their taxpayers. Billboards stubborn in terms of installation without going through the procedures. This happens because the taxpayer feels that the procedure / mechanism permits for the installation of billboards considered too complicated, so they are reluctant to take care of these licenses.

b. Lack of awareness. Mounting billboard as a taxpayer to pay the advertisement tax. For example, the installation of billboards through flyers, leaflets are often found not diporporasi before distribution. Porporasi is perforate leaflets as a sign of the flyer was paid taxes and is ready for distribution.

\subsection{Initiatives by the Regional Finance Agency (BKD) Sukoharjo}

There were several attempts made by the Field income of Sukoharjo to Overcome the obstacles in the implementation of advertisement taxation. Such efforts are divided into two as follows:

1. Receipt trying to bringcomplete equipment for the demolition of billboards that have expired. Equipment to do the demolition, among others car field and ladders

2. be formedSpecial teams / team arrangement of advertisement by DPPKA to supervise, monitor, regulate billboard placement consisting of DKP, DLLAJ, and DPU

3. Collecting data on active and passive. Active data collection is done by tax officials come directly concerned taxpayer. While the passive data collection is done by taxpayer came alone to the Tax Office

4. Mechanisms to curb the Taxpayers meet directly concerned by the collector officers if found unlicensed billboards or commercials Taxpayer licensed but not yet paid advertising tax up to the prescribed time limit.

5. Give extension to taxpayers advertisement to better know and understand about the procedures and mechanisms for licensing and payment of the advertisement tax

\section{CONCLUSION AND \\ RECCOMENDATION}

\subsection{Conclusion}

Based on the results of research and discussion has been done on the contribution rate of the advertisement tax to PAD Sukoharjo it can be concluded that the advertisement tax revenue contribution to the Local Tax Revenue with an average of $3.06 \%$. While the advertisement tax revenue contribution to PAD Sukoharjo district for 5 years is still included in the criteria is very less with an average of $1.50 \%$. The result meant that the advertisement tax management need to be considered to be optimal.

The lack of active role of the Sector Income Sukoharjo district in the dissemination of the advertising tax to the public, causing a lack of awareness of the taxpayer in carrying out tax obligations. Besides the lack of human resources also need to be considered. This certainly can give effect to the achievement of the advertisement tax revenue target set by the Revenue Division Sukoharjo so that will impact the 
International Journal of Economics, Business and Accounting Research (IJEBAR)

Peer Reviewed - International Journal

Vol-1, Issue-1, 2017 (IJEBAR)

ISSN: 2614-1280

http://jurnal.stie-aas.ac.id/index.php/IJEBAR

advertisement tax contribution to local revenue.

\subsection{Recommendation}

Based on the obstacles related to the process of advertisement tax collection, the authors sought to provide feedback or suggestions to the Regional Financial Sector Revenue Agency Sukoharjo as follows:

1. Need to do the data collection of objects existing advertisement tax that new potentials on the billboard tax can be recorded properly

2. Optimizing new potentials untapped by Sector Income Sukoharjo district in order to maximize the advertisement tax revenue

3. Needs to be disseminated regularly and evenly to taxpayers about the importance of advertisement tax to support public welfare

4. Revenue field it is necessary Sukoharjo provides strict sanctions against taxpayers who lack discipline in executing tax obligations

5. Necessary to add the tax collector competent officer that the tax collection process to run smoothly and organized

\section{BIBLIOGRAPHY}

Arikunto, Surhasani. 2002. Prosedur Penelitian Suatu Pendekatan Praktik. Jakarta: Rineka Cipta

Arvian Triantoro. 2010. Efektifitas Pemungutan Pajak Reklame dan Kontribusinya Terhadap Penerimaan Pajak Daerah di Kota Bandung. Universitas Pendudukan Indonesia Bandung

Fitriani (2012). Kontribusi Pajak Reklame Dalam Meningkatkan Pendapatan

Asli Daerah Pada Dinas Pendapatan Daerah. Skripsi FKIP Universitas Tanjungpura Pontianak

Halim, Abdul. 2004. Bunga Rampai Manajemen Keuangan Daerah. Edisi Revisi. Yogyakarta: Unit Penerbit dan Percetakan AMP YKPN.

Halim, Abdul. 2004. Akuntansi Keuangan Daerah Edisi Revisi. Jakarta: Salemba Empat.

Indrawan, Rizki (2015). Pengarug Kontribusi Pajak terhadap Pendapatan Asli Daerah (studi Kasus pada Dinas Pendpatan Daerah Kota Bandung), Portofolio Vo. 12 Nomor 2 November 2015, 166-185.

Nasir, Mohammad. 2003. Metodologi Penelitian. Cetakan Keempat. Jakarta: Ghalia Indonesia

Peraturan Daerah Kabupaten Sukoharjo Nomor 7 tahun 2011 tentang Pajak Daerah.

Peraturan Daerah Kabupaten Sukoharjo Nomor 5 Tahun 2014 Tentang Penyelenggaraan Reklame

Peraturan Daerah Kabupaten Sukoharjo Nomor 12 Tahun 2016 Tentang Pembentukan dan Susunan Perangkat Daerah

Purba, R dan Ginting, Rika MH (2016). Pengaruh Pajak Reklamedan Pajak Penerangan Jalan Terhadap Pendapatan Asli Daerah Kota Medan. Jurnal Mutiara Akuntansi 20 Oktober 2016. Hal 25-31.

Resmi, Siti. 2016. Perpaja kan: Teori dan Kasus. Jakarta: Salemba Empat

Rochmat Soemitro. 2007. Dasar-dasar Hukum Pajak dan Pajak Pendapatan. Bandung: Eresco

Sugiyono. 2012. Metode Penelitian Kuantitatif Kualitatif dan $R \& D$. Yogyakarta: Alfabeta

Undang-undang Nomor 28 Tahun 2009 tentang Pajak Daerah dan Retribusi Daerah. 
International Journal of Economics, Business and Accounting Research (IJEBAR)

Peer Reviewed - International Journal

Vol-1, Issue-1, 2017 (IJEBAR)

ISSN: 2614-1280

http://jurnal.stie-aas.ac.id/index.php/IJEBAR

Undang-Undang Nomor 28 Tahun 2007 tentang Ketentuan Umum Dan Tata Cara Perpajakan.

Waluyo. 2014. Perpajakan Indonesia. Jakarta: Salemba Empat 